Stellenbosch Theological Journal 2020, Vol 6, No 3, 171-248

DOI: http://dx.doi.org/10.17570/stj.2020.v6n3.a7

Online ISSN 2226-2385 | Print ISSN 0028-2006

2020 ๑ Pieter de Waal Neethling Trust

\title{
'n Kerkhistoriese oorsig van die diskoers oor rasseverhoudinge en versoening in die Afrikaanse gereformeerde kerke (1990-2017)
}

\author{
Mary-Anne Plaatjies-Van Huffel $\dagger(1959-2020)$ \\ Universiteit Stellenbosch \\ Stellenbosch, Suid-Afrika
}

\begin{abstract}
A church-historical analysis of the discourse on race relations and reconciliation in the Afrikaans reformed churches (1990-2017)

The Afrikaans Reformed Churches, namely the Dutch Reformed Church (DRC), Uniting Reformed Church in Southern Africa (URCSA), Nederduitsch Hervormde Kerk of Africa (NHKA) and the Reformed Churches in South Africa (RCSA) made choices regarding the theological justification of apartheid and/or the denouncement thereof. in the past three decades. This chapter offers a close reading of synodical decisions of the Afrikaans Reformed churches with regard to the theological justification of apartheid and related issues as well as the resolutions of the General Assembly of the World Alliance of Reformed Churches in 1992. The decisions of the said churches led to the re-admission of the NHKA and DRC in national and international ecumenical organisations, but eventually resulted in some schisms in the denominations. The chapter highlights the reluctance of the Afrikaans reformed churches to expedite a response to the World Alliance of Reformed Churches' resolutions connected to the biblical justification of apartheid and to attend to reconciliation. In this chapter, attention will be paid to the following sub-themes: the struggle against the theological justification of apartheid and its legacy; from the theological justification of apartheid to a season of human dignity (DRC); from "volkskerk" to identity determined by God (NHKA); the protection of the identity of the "volk" as a God-given call to demographic unity (GKSA); jointly together towards a theology of inclusivity.
\end{abstract}

Trefwoorde

Gereformeerde kerke in Suid-Afrika; rasseverhoudinge; apartheid; interkulturaliteit; inklusiwiteit; menswaardigheid 


\section{Inleiding}

Die Afrikaanse gereformeerde kerke, naamlik die Nederduitse Gereformeerde Kerk (NGK), die Verenigende Gereformeerde Kerk in Suider-Afrika (VGKSA), die Nederduitsch Hervormde Kerk van Afrika (NHKA) en die Gereformeerde Kerke in Suid-Afrika (GKSA) het die afgelope drie dekades posisie-keuses gemaak met betrekking tot die teologiese regverdiging van apartheid of die afwysing daarvan. Die besluite van vermelde kerke het tot die heropname van die NHKA en die NGK in nasionale en internasionale ekumeniese organisasies gelei, maar het uiteindelik in bepaalde gevalle ook tot kerkskeuring gelei. Die vraagstelling wat in hierdie artikel aangespreek word, wentel om die vraag hoe die verskillende Afrikaanse gereformeerde kerke in Suid-Afrika op ooreenstemmende of verskillende wyses meegewerk het aan die skepping van'n teologie van apartheid en uiteindelik ook via dekonstruksie, betrokke geraak het by 'n teologie van inklusiwiteit. Die volgende subvrae kom dus aan die orde: die stryd teen die teologiese regverdiging van apartheid en die nalatenskap van apartheid (VGKSA); van teologiese regverdiging van apartheid tot die Seisoen van Menswaardigheid (NGK); van volkskerk tot identiteit bepaal deur God (NHKA); die beskerming van volksidentiteit as 'n Godgegewe roeping na demografiese eenheid (GKSA); en gesamentlik op weg na 'n teologie van inklusiwiteit.

\section{Die stryd teen die teologiese regverdiging van apartheid en die nalatenskap van apartheid}

Apartheid verwys na 'n politieke bestel, ideologie en beleid wat op rasseklassifikasie gegrond is. Apartheid was geïnstitusionaliseer in die wetgewing, beleide en strukture, selfs kerklike strukture, in Suid-Afrika sedert 1949 tot 1994 (Agenda en Handelinge NGSK 1982:378-379, 431443). Hierdie wetgewing ${ }^{1}$ het afsonderlike ontwikkeling op ekonomiese, politieke, geografiese en sosiale vlak verseker. Tot die 1970's was daar

1 Apartheid wetgewing sluit onder meer in die Wet op Verbod van Gemengde Huwelike, Wet No 55 van 1949, Groepsgebiedewet, Wet No 41 van 1950, Wet op Bevolkingsregistrasie, Wet No 30 van 1950, Ontugwet, Wet No. 21 van 1950, Wet op Bantoe-owerhede, Wet No 68 van 1951, Wet op die Afsonderlike Verteenwoordiging van Kiesers, Wet No 46 van 1951, Wet op die Voorkoming van Onregmatige Plakkery, Wet No 52 van 1951, Naturellewet: Afskaffing van Passe en Koördinering van Dokumente, 
weinig teologiese kritiek teen die stelsel van apartheid vanuit die geledere van die ras-gesegregeerde kerke in Suid-Afrika, naamlik die Nederduits Gereformeerde Sendingkerk (NGSK), die Nederduits Gereformeerde Kerk in Afrika (NGKA) en die Reformed Church in Africa (RCA). Bovermelde kerke het as gevolg van die sendingywer van die NGK ontstaan, naamlik die NGSK in 1881 vir sogenaamde bruin Afrikaanssprekende lidmate. In 1910 het afsonderlike kerke vir swart mense onstaan, wat later as die NGKA bekend sou staan, en in 1968 is 'n afsonderlike kerk vir Indiërs gekonstitueer.

Ras, Volk en Nasie (1975: 31) is 'n teologiese regverdiging van apartheid wat in baie opsigte 'n dokument van sy tyd was en wel in die hoogbloeijare van apartheid. Ras, Volk en Nasie stel dit ondermeer onomwonde dat die Nuwe Testament volkeverskeidenheid aanvaar (Gal 3:26), dat die verskille in volksverband, sosiale posisie, geslag nie opgehef word in die sigbare kerk nie, maar dat dit veel eerder in Christus geheilig word.

Die VGKSA dui aan in hul verslag aan die Waarheids- en Versoeningskommissie dat die NGSK eers in 1978 teologiese kritiek op Ras Volk en Nasie gelewer het (Agenda en Handelinge NGSK 1978:200). Die NGSK Sinode 1978 het gevolglik verklaar dat apartheid grotendeels berus op die "teologiese en morele regverdiging" van die stelsel en dat apartheid en die morele en teologiese regverdiging daarvan 'n teologiese kettery is (Agenda en Handelinge NGSK 1978:2, 21). Die NGSK het die Wêreldraad van Kerke se "Programme to Combat Racism" op die NGSK Sinode 1982 in behandeling geneem en het 'n resolusie aanvaar waarin hul die teologiese regverdiging van apartheid as sonde veroordeel het (Agenda en Handelinge NGSK 1982:210-250). Die rassisme van apartheid is gevolglik as 'n strukturele en institusionele sonde verklaar.

Die teologiese regverdiging van apartheid deur die Suid-Afrikaanse lidkerke van die Wêreldbond van Gereformeerde Kerke (WBGK), naamlik die NGK en die Nederduitsch Hervormde Kerk in Afrika (NHKA), het ook die WBGK uitgedaag. Die WBGK het op hul Algemene Vergadering in Ottawa gedurende 1982 verklaar dat die teologiese regverdiging van apartheid 'n 
kettery is aangesien dit onversoenbaar is met die Bybelse boodskap van eenheid in die liggaam van Christus (WARC General Council 1983:177; 1990:173-175, 279-281). Die WBGK het gevolglik die lidmaatskap van die NGK en die NHKA opgehef (dit wil sê, die NGK en die NHKA kon nie meer afgevaardigdes na die algemene vergadering van die WBGK stuur nie of deel wees van die komitees of kommissies van die WBGK nie). Die WBGK het die volgende vereistes gestel wat die NGK en die NHKA moes nakom alvorens hul skorsing opgehef sou kon word:

- Swart Christene word nie meer van kerkdienste uitgesluit nie, veral van die Nagmaal.

- Steun in woord en daad word gegee aan diegene wat onder die apartheidstelsel (of afsonderlike ontwikkeling) ly.

- Ondubbelsinnige sinodebesluite word gemaak wat apartheid verwerp en die kerk verbind om die stelsel in sowel die kerk as die politiek af te breek (WARC General Council Proceedings1983:176-180; WARC Called to Witness 1983:26-30).

Die NGSK Sinode 1982 het op voetspoor van die WBGK, 'n status confessionis verklaar. Die NGSK het verklaar dat aangesien die teologiese regverdiging van apartheid die Bybelse boodskap van versoening in gedrang bring, hulle nie anders kan as om 'n belydenis te formuleer nie. Op die sinode het vyf persone, te wete proff Dirkie Smit, Gustav Bam, Jaap Durand, en drr Allan Boesak en Isak Mentor, opdrag gekry om 'n belydenis op te stel en gedurende die sitting aan die Sinode voor te lê vir goedkeuring. Die belydenis staan bekend as die "Belydenis van Belhar" en is uiteraard 'n belydenis teen die teologiese regverdiging van apartheid. Die woord Belhar verwys na die voorstad waar die sinodesitting van die NGSK plaasgevind het. Die Belydenis beklemtoon die volgende pilare, naamlik eenheid, versoening, geregtigheid. Op die NGSK Sinode 1986 was die Belhar-belydenis as vierde geloofsbelydenis aanvaar (Agenda en Handelinge NGSK 1986:718-747).

Die Belhar-belydenis verwys na gelowiges as die "volk van God" en beklemtoon dat "ware geloof in Jesus Christus die enigste voorwaarde is vir lidmaatskap van hierdie kerk" (Belhar-belydenis 1986). Hiermee wys die VGKSA die konstituering van ras-gesegregeerde kerke op teologiese gronde af. Die Belhar-belydenis is 'n teologiese kritiek op die teologiese 
regverdiging van "volkeverskeidenheid" en "afsonderlike ontwikkeling” en "parallelle ontwikkeling" soos aangedui in Ras Volk en Nasie (1975:31). Die Belhar-belydenis stel dit duidelik dat die kerk "enige leer verwerp wat óf die natuurlike verskeidenheid óf die sondige geskeidenheid so verabsoluteer dat hierdie verabsolutering die sigbare en werksame eenheid van die kerk belemmer (Belhar-belydenis 1986).

Desnieteenstaande bovermelde het die stigting van die VGKSA tot kerkskeuring en onversoenheid tussen VGKSA en die NGKA gelei en tot die voortsetting van die NGKA as denominasie vir swart mense soos dit blyk uit die hofsaak tussen die NGKA en die VGKSA 1996-1998 (NGKA vs VGKSA saaknommer 536/96:31). Sedert 1998 tot 2012, na uitspraak ten gunste van die NGKA gelewer is, was ongeveer 40 gemeentes van die VGKSA en die NGKA in hofgedinge insake eiendomsreg van kerkeiendom betrokke. 'n Groot mate van onversoendheid het tussen gemeentes geheers. Eers op 7 Desember 2012 kon 'n skikkingsooreenkoms buite die hof tussen die NGKA en die VGKSA gemeentes deur die bemiddeling van die NGK bereik word. Die NGK het R1 miljoen bewillig. Die ooreenkoms het bepaal aan wie eiendomsreg van watter kerkgeboue toegeken sou word, asook die skikkingsbedrag wat aan of die NGKA of die VGKSA geallokeer sou word (DRC/DRCA/URCSA Church Property Settlement 2012:1).

Min is deur die VGKSA gedoen om multi-etniese gemeentes in die VGKSA daar te stel. Weens diefeit dat geen groot demografiese skuiwe met betrekking tot die woonbuurte soos gekonstitueer deur die apartheidswetgewing post 1994 plaasgevind het nie, is die profiel van gemeentes van die VGKSA onveranderd gelaat. By implikasie het die gemeentes in die voormalige swart woonbuurte hoofsaaklik swart lidmate, terwyl in die woonbuurte voorheen gereserveer vir bruin mense, bruin Afrikaanssprekende lidmate van die VGKSA. Slegs enkele multi-kulturele gemeentes kom voor in die VGKSA. Dit werk negatief in om rasseverhoudinge en interkulturaliteit op plaaslike vlak te bevorder. Die VGKSA sukkel, soos uit polariserende gesprekke op sinodale en bedieningsvlak die afgelope 25 jaar met betrekking tot interne eenheid blyk, insake kulturele identiteite (bevordering van eie taal of kultuurgroepe), taal, en verkiesing van persone uit verskillende taalgroeperinge in die leiersposisies van die kerk, onder andere. Die VGKSA sal veel meer moet doen om die teologiese voorveronderstellings met betrekking tot identiteitspolitiek wat in die 
VGKSA verskuil lê, te dekonstrueer en te vervang met wat Eung Chun Park'n teologie van inklusiwiteit noem, naamlik “... to include Gentiles in the God's fold without making them to become Jews through circumcision and by observing Jewish laws" (2003:2). Veel meer sal gedoen moet word om interkulturaliteit, wat meer is as om bloot voorsiening te maak vir veeltaligheid, veral op gemeentevlak te bevorder.

\section{Van teologiese regverdiging van apartheid tot die Seisoen van Menswaardigheid (NGK)}

Die NGK het aanvanklik nie aandag gegee aan die drie vereistes wat die WBGK gestel het wat die NGK moes nakom alvorens hul skorsing opgehef sou kon word nie. In 1982 het die Algemene Sinode van die NGK veel eerder besluit dat Ras Volk en Nasie "indringend in die lig van die Skrif hersien" behoort te word vir oorweging deur die volgende Algemene Sinode (Handelinge NGK 1982:1182). Die aanvaarding van Kerk en Samelewing as nuwe beleidstuk van die NGK in 1986 het uiteindelik gelei tot die stigting op 27 Junie 1987 van die "Die Afrikaanse Protestantse Kerk - 'n Gereformeerde Kerk van Christus onder blanke Afrikaners". Met betrekking tot lidmaatskap dui die stigtingsakte van die nuwe kerk "dat slegs blanke Afrikaners en ander blankes wat hul met die blanke Afrikaners vereenselwig, lidmaatskap van hierdie kerk mag geniet" (Van der Merwe 1990:670). Barend van der Merwe en Marietjie Oelofse (2011:156) dui aan die stigting van die Afrikaanse Protestante Kerk was "die direkte gevolg van die NGK se besluit dat die Bybel geen gronde vir die bestaan van 'n beleid van rasseskeiding bied nie".

In Maart 1989 is die Vereeniging-verklaring uitgereik deur die verteenwoordigers van die verskillende lidkerke van die NG Kerkfamilie. In die verklaring word apartheid in al sy vorme as sonde verwerp en verbind die lede van die NGK-familie hul om apartheid in sowel kerk as staat af te breek deur die eenwording van die verskillende kerke in een nie-rassige gereformeerde kerk in suidelike en sentrale Afrika te aanvaar, en deur 'n oproep aan die staat te doen om alle rassistiese wette en onderdrukkende veiligheidswetgewing te herroep (WARC General Council Proceedings 1990:279-281). Die verklaring het egter nie noodwendig gelei tot die NGK 
se afwysing van apartheid nie. Veel eerder sou dit etlike jare duur alvorens die NGK ag sou slaan om die resolusie van die WBGK 1992 na te kom.

Daarom het die WBGK in Seoul 1990 die voorwaardes wat deur die Algemene Vergadering van die WBGK 1982 vasgestel was, herbevestig. In 1994, het die NGK aan die WBGK gerapporteer dat hul al drie vereistes wat die WBGK neergelê het, nagekom het (Agenda NGK Algemene Sinode 1994:144; Besluiteregister NGK Algemene Sinode 1994:16-17).

Voor die Algemene Vergadering van die WBGK in Debrecen, Hongarye, Augustus 1997, het 'n taakspan van die WBGK die NGK besoek. Dit het geblyk dat dit moeilik vir die WBGK was, desondanks Kerk en Samelewing, om ondubbelsinnige sinode- en moderamen-besluite te vind waarin die NGK apartheid verwerp en die kerk aangemoedig word om die stelsel in die kerk en staat af te breek. Die WBGK het egter aangedui dat die NGK slegs die eerste twee vereistes nagekom het, naamlik die opening van eredienste vir alle rasse en die verskaffing van hulpverlening aan die slagoffers van apartheid. Ondubbelsinnige sinodebesluite waarin apartheid verwerp word en waarin die NGK homself verbind om die stelsel in kerk en politiek af te breek, het egter ontbreek (WARC General Council 1997 A pastoral letter). Op die Algemene Vergadering in Debrecen het die WBGK gevolglik 'n gesamentlike pastorale brief wat betrekking het op die hertoelating van die NGK tot die WBGK goedgekeur. Die NGK en die WBGK was medeondertekenaars van die brief.

In hul voorlegging aan die Waarheids- en Versoeningkommissie het die NGK aangedui dat die foute en sondige optrede van apartheid meer in die implementering van apartheid geleë is as in sy fundamentele aard (The Story of the Dutch Reformed Church's Journey with Apartheid 1997:35-36). Die verhaal van die 1994 se reis met apartheid toon 'n kentering in die NGK en 'n verskuiwing in die denke van die NGK met betrekking tot die teologiese regverdiging van apartheid. Die WBGK was egter van mening dat aangesien die aard van gedwonge skeiding van mense van verskillende rasse die basiese Bybelse leer ontken dat die hele mensdom gelykwaardig na die beeld van God geskape is, 'n leer wat so sentraal aan die Christelike geloof is, dat dit nie deur Christene ontken kan word sonder dat hulle hul Christenwees ontken nie. Die WBGK het gevolglik geëis dat die NGK 'n resolusie, wat deur die WBGK opgestel was, waarin die ondubbelsinnige 
verwerping van apartheid verklaar word, sou medeonderteken. Die formulering in Kerk en Samelewing was nie as genoegsaam beskou nie. Die WBGK was van mening dat die voorgestelde gesamentlike besluit, indien goedgekeur deur die NGK, sou aan die laaste vereiste van die WBGK 1982 voldoen, naamlik "ondubbelsinnige sinodebesluite word gemaak wat apartheid verwerp en die kerk verbind om die stelsel in beide kerk en politiek af te breek" (WARC General Council 1983:176-180; WARC Called to Witness 1983:26-30).

Met betrekking tot die verklaring dat apartheid 'n kettery is, dui die WBGK in die Pastorale Brief aan die NGK, gedateer 1997, aan dat "kettery die aanhoudende en doelbewuste onderrig is van valse leerstellings nadat die breër kerk die fout uitgewys het" (WARC General Council 1997 - A pastoral letter). Hierdie term beklemtoon die WBGK se standpuntinname dat die teologiese regverdiging van apartheid nie bloot 'n fout was met betrekking tot die leer van die kerk of 'n meningsverskil in sake waar daar vryheid bestaan om te verskil nie, maar eerder is dit'n fundamentele perversie en deformasie van die hart van die evangelie (WARC General Council 1997 A pastoral letter). Die NGK Algemene Sinode 1998 het die gesamentlike resolusie soos opgestel deur die WBGK goedgekeur. Met die besluit was die NGK se reg tot volle deelname in die WBGK herstel. Die sinode het verder verklaar dat die substantiewe inhoud van die Belharbelydenis ("ons verbintenis tot die Bybelse getuienis oor die drie-enige God, die eenheid van die kerk, oor geregtigheid en versoening") wyd in die NGK aanvaar is (Acta Algemene Sinode NGK 1998:422-425). Die sinode het dus die wesenlike inhoud van die Belhar-belydenis aanvaar. Die NGK se voorveronderstelling was dat die besluit nie noodwendig impliseer dat alle gemeentes, predikante, kerkraadslede en lidmate van die beoogde verenigde kerk verplig sou wees om die Belhar-belydenis as 'n belydenis te onderskryf nie. Die Algemene Sinode van 1998 het verklaar dat die Belharbelydenis nie in stryd is met die ander gereformeerde belydenisse nie. Die Algemene Sinode van 1998 het egter ook aangedui dat al die streeksinodes van die NGK die aanvaarding van die Belydenis van Belhar as deel van die geloofbasis van 'n herenigde kerk verwerp het (Agenda Algemene Sinode NGK 1998:422-425; Besluiteregister Algemene Sinode NGK 1998:16).

Die Algemene Sinode van die NGK van 2004 het voorgestel dat die Belydenis van Belhar in die geloofbasis van die verenigde kerk ingesluit 
behoort te word, aangesien die essensie van die belydenis reeds in 1998 deur die Algemene Sinode van die NGK aanvaar is. Die Sinode het verder ook besluit dat elke gemeente hul eie besluit met betrekking tot die belydenis kon maak. Die Sinode het verder aangedui dat die weerstand teen die belydenis aan historiese, emosionele en simboliese faktore toegeskryf kon word (Besluiteregister Algemene Sinode NGK 2004:1-4). Die Sinode het 'n konsultasieproses goedgekeur en die besluit met betrekking tot die Belhar-belydenis na die sinodes, kerkrade en gemeentes verwys vir kommentaar en verdere aanbevelings. Die Sinode van 2004 het bevestig dat alhoewel daar baie predikante en kerklidmate was wat gereed was vir kerkhereniging en om die Belhar-belydenis te onderskryf, was daar ook baie predikante en kerklidmate wat om verskeie redes nie die Belydenis van Belhar as 'n belydenis wou onderskryf nie. Die NGK-standpunt was dat die kerk 'n verantwoordelikheid vir al hierdie groepe gehad het en het gevolglik 'n proses van kerkhereniging voorgestel wat die idee van 'n ruim huis omhels wat ruimte vir almal sou bied (Besluiteregister Algemene Sinode NGK 2004:1).

Die NGK het gedurende 2010-2015 aansoek om hertoetrede tot die Suid Afrikaanse Raad van Kerke en die Wêreldraad van Kerke gedoen, asook lidmaatskap by die All Africa Conference of Churches. Die VGKSA het die aansoeke van die NGK heelhartig ondersteun. Dit word allerweë in die ekumene as tekenend van die versoening tussen die twee kerke beskou.

Die VGKSA, NGK, NGKA en die RCA het gedurende 2010 besluit om gesamentlik 'n "Seisoen van Menswaardigheid' aan te pak. Die doel van die Seisoen van Menswaardigheid sou dien as 'n ruimte waarbinne nadenke en dialoog oor menswaardigheid bevorder word. Agt verskillende temas vir bespreking is geïdentifiseer waaronder die verskillende kerke se bydraes tot die bevordering, die regverdiging of stryd teen apartheid.

\section{Van volkskerk tot identiteit bepaal deur God (NHKA)}

Die NHKA het nie voorleggings aan die Waarheid- en Versoeningskommissie gemaak met betrekking tot hul rol in die bevordering, verdediging of regverdiging van en of stryd teen apartheid nie. Artikel III van die Kerkwet van die NHKA het lidmaatskap van die NHKA tot witmense beperk: 
Artikel III. Die Kerk, bewus van die gevare wat vermenging van blank en nie-blank vir al twee groepe inhou, wil geen gelykstelling in sy midde toelaat nie, maar beoog die stigting van eie volkskerke onder die verskillende volksgroepe, in die oortuiging dat aldus die bevel van die Here - "Maak dissipels van alle nasies" (Mat 28:19) die beste tot sy reg sal kom en dat die eenheid in Christus deur so 'n werkverdeling nie geskaad sal word nie. Tot die Nederduitsch Hervormde Kerk van Afrika behoort daarom net blanke persone (NHKA Kerkwet 1951 Artikel III).

Wim Dreyer dui daarop dat die term "geen gelykstelling" die begrip "apartheid" vooraf gegaan het (Dreyer 2013:2). Die NHKA het in 1951 "geen gelykstelling" en "volkskerk" gebruik om die lidmaatskap van die NHKA tot wit mense te beperk. Alreeds op 14 April 1960 het die Algemene Kerkvergadering verklaar dat die NHKA se "diepste oortuiging is dat aparte ontwikkeling die enigste, Christelik[-] gefundeerde, regverdige beleid" vir Suid-Afrika is. Die Algemene Kerkvergadering het verder ook aangedui dat

... dit'n Christen kerk betaam om aan die Bantoe openlik en eerlik te sê dat ons hom nie in ons Kerk wil opneem nie, omdat dit onregverdig, onbroederlik en onverantwoordelik is om van hom te verwag dat hy 'n namaaksel van ons blankes moet word. Ons gun hom wat ons vir onsself opeis, naamlik dat hy God sal dien in 'n eie selfstandige Kerk waar hy deur sy eie leraars bedien kan word en, in ooreenstemming met "sy eie volksaard en in sy eie taal, God kan verheerlik". Bovermelde besluite toon duidelik die NHKA se standpuntname oor "volkskerk", "eie volksaard" en teologiese regverdiging van apartheid.

AD Pont beskryf in talryke artikels die NHKA positief as "volkskerk". (Pont 1969:202-218; Pont 1986:28-76; Pont 1991:783-799). Volgens Buitendag (2006:813) kom die begrip “volkskerk", in die NHKA se kerkwet uit die politieke en kulturele aspirasies van die Afrikaner sedert die 19de eeu. Volgens Wim Dreyer het die NHKA 'n "nou verbondenheid tussen kerk, volk en owerheid” gehandhaaf (Dreyer 2006:1337).

Die WBGK het op hul Algemene Vergadering in Ottawa gedurende 1982 die lidmaatskap van die NHKA opgehef. Die WBGK het dieselfde drie 
vereistes (as aan die NGK) aan die NHKA gestel wat nagekom moes word alvorens hul skorsing opgehef sou kon word. Die NHKA was van mening dat apartheid nie met rassisme geïdentifiseer word nie en het gevolglik bande met die WBGK verbreek (NHKA 69e Algemene Kerkvergadering 2010:326). Op die 61ste, 62ste en 63ste Algemene Kerkvergaderings van 1986, 1989 en 1992 van die NHKA het geen verslae oor die WBGK gedien nie. Daar is gevolglik geen besluite geneem wat verband gehou het met die besluit van die WBGK om die NHKA se lidmaatskap op te skort nie.

'n Nuwe politieke dispensasie het in 1994 in Suid Afrika aangebreek. Die 64ste Algemene Kerkvergadering van 1995 het opdrag aan die Raad vir Ekumene gegee om aandag te gee aan sake wat verband hou met die WBGK se resolusie van 1982 met betrekking tot die vereistes wat hul moes nakom alvorens die skorsing opgehef sou kon word.

Die Herderlike Skrywe van die NHKA, getiteld "Kerk en politiek" (NHKA 1990) toon 'n duidelike verskuiwing in denke van die NHKA. In die skrywe word dit deurgegee dat die NHKA elke vorm van rassisme verwerp waar een volk of ras hom afgodies verhef teenoor ander volke of rasse.

Die Kerk verwerp as onversoenbaar met Christelike verantwoordelikheid, enige krenkende, beledigende of vernederende reëling of optrede tussen mens en mens op welke terrein ook al, sowel as enige oorbeklemtoning van eie waardigheid, eer of bevrediging ten koste van die geluk en heil van ander mense (NHKA Herderlike Skrywe 1990; NHKA 69e Algemene Kerkvergadering 2010:351).

In vergelyking met die Verklaring van die Algemene Kerkvergadering van die NHKA 14 April 1960 en die Herderlike Skrywe van 1973, verteenwoordig die skrywe van 1990 'n fundamentele skuif, nie soseer deur wat daar geskryf staan nie, maar deur wat weggelaat is. Byvoorbeeld in die Herderlike Skrywe van 1990, is daar geen uiteensetting of verdediging van apartheid of Artikel III nie. Daarteenoor het die Herderlike Skrywe 1973 dit onomwonde gestel "dat die NHKA alle vorme van integrasie in kerk en staat teenstaan" (Dreyer 2013:5). In die Herderlike Skrywe 1973 word gevolglik 'n teologiese begronding vir apartheid aangebied. Daarteenoor word in die Herderlike Skrywe 1990 "die sending aan ander volke as die gelowiges se belangrikste roeping beklemtoon en word enige vorm van 
rassisme, asook enige rassistiese maatreëls wat die waardigheid van mense aantas, verwerp" (Dreyer 2013:5).

Artikel III van die Kerkwet van die NHKA is in 1997 gewysig en is vervang met Ordereël 4 wat lees: "Die Kerk 'n volkskerk is met sy eie kerklike kultuur, geskiedenis, taal en tradisie wat geroepe is tot die verkondiging van die evangelie van Jesus Christus aan die Afrikanervolk en tegelyk aan alle mense" (NHKA Kerkwet 1997:69). In wese word die volkskerkgedagte in die formulering van 1997 behou en daarmee saam die teologiese begronding van apartheid. Die 65ste Algemene Kerkvergadering van 1998 van die NHKA het kennis geneem van 'n artikel oor die vraag, "Moet die Afrikaanse Kerke skuld bely oor apartheid?", wat prof IWC van Wyk geskryf het. Geen besluite is egter op die kerkvergadering geneem met betrekking tot die verhouding met die WBGK en/of sake wat direk verband hou met die resolusies van die WBGK 1982 nie (NHKA 69ste Algemene Kerkvergadering 2010:327).

Op die 66ste Algemene Kerkvergadering van die NHKA 2001 is die memorandum van DJC van Wyk (snr) in sake die saak van'n skuldbelydenis oor apartheid, sonder bespreking, as 'n kompromis aanvaar. In die skuldbelydenis oor apartheid stel die Algemene Kerklike Vergadering dit dat die kerk:

... kennis neem van die misdade wat onder die apartheidsbeleid gepleeg is, selfs deur lidmate van die Kerk. Daarvoor bely die Kerk sy skuld voor God en word die lidmate opgeroep tot 'n skuldbelydenis teenoor God en medemens. Dit sluit ook in dat die NHKA kennis geneem het van gruweldade wat onder die vaandel van die apartheidsbeleid gepleeg is, ook deur die Kerk se eie lidmate. Die Kerk spreek sy smart en berou voor God daaroor uit. Hierdie Algemene Kerkvergadering is diep bewus van ons Kerk se sonde, in die volle skrikwekkende omvang wat die Bybel daaraan gee: Haat, vyandskap, opstand, liefdeloosheid, ongehoorsaamheid en nalatigheid teenoor God en medemens" (NHKA, 66ste Algemene Kerkvergadering 2001:171-174).

Dit is volgens Dreyer opvallend van hierdie skuldbelydenis dat apartheid as stelsel nie veroordeel word nie, slegs die dade wat mense onder apartheid gepleeg het, word veroordeel. Die indruk word volgens Dreyer dus gelaat 
dat apartheid as politieke stelsel soos ander politieke stelsels as neutraal beskou word (Dreyer 2013:1).

Die 67ste AKV van 2004 het besluit dat die NHKA moet aansoek doen om herstel van lidmaatskap van die Reformed Ecumenical Council (REC) en die WBGK (NHKA 2004:171). Die REC het die aansoek van die NHKA goedgekeur, terwyl die WBGK dit eers in 2007 sou oorweeg toe die NHKA aan die vereistes van die Ottawa resolusies voldoen het (NHKA Algemene Kerkvergadering 2006; NHKA Kommissie van die Algemene Kerkvergadering 2006.). Hierdie vereistes sluit in:

- Die NHKA moet erken dat apartheid in sy wese rassisties en daarom sondig is;

- Die teologiese en etiese begronding wat die NHKA soos ander kerke, aan apartheid en afsonderlike wit en swart kerke gegee het, was en is 'n ernstige dwaalleer;

- Die gesprek oor eenwording tussen die NHKA en die Hervormde Kerk van Suidelike Afrika(HKSA) (hul kerk vir swart mense) moet op dreef kom;

- Teologiese studente moet gesamentlik opgelei word; en

- Ordereël 4 van die Kerkorde se verwysing na volkskerk moet geskrap word.

Die Kommissie van die Algemene Kerkvergadering het in 2006 'n memorandum getiteld "Identiteit en Relevansie van die NHKA aan die begin van die 21ste eeu in Suid-Afrika" aanvaar. Hierdie memorandum het as besprekingsdokument gedien by'n Nasionale Colloquium wat van 27 tot 29 April 2006 plaasgevind het. Tydens die colloquium het afgevaardigdes die volgende verklaring geformuleer:

Wat ons uniek in die wêreld maak, is dat ons identiteit bepaal word deur die waardes van God se Koninkryk en nie dié van die wêreld nie. Hoewel 'n andersoortige gemeenskap, kry die kerk gestalte in die konteks van eie tradisie, kultuur en taal. Hierdie roeping moet ons teenoor alle mense uitleef en die term "volkskerk" kan ons hierin beperk ... Ons sien pluriformiteit en diversiteit nie as 'n bedreiging nie en oordeel nie dat almal uit een mond hoef te praat nie. Anders as verskeidenheid is die eenheid van die kerk egter wel 
die evangeliese eis. Eie voorkeure mag nie tot konflik of onenigheid lei nie, maar moet saamklink soos 'n simfonie tot eer van God (NHKA 69e Algemene Kerkvergadering 2010:345).

In 2009 het die WBGK se Uitvoerende Komitee die NHKA besoek. Geen vordering met betrekking tot die kwessie van hertoetrede tot die WBGK kon gemaak word nie. Die 69ste Algemene Kerkvergadering het die saak met betrekking tot die hertoetrede tot WBGK terugverwys vir verdere studie. Die volgende voorstel van drr PB Boshoff en FJ Boshoff was op die vergadering in ag geneem:

Die Algemene Kerkvergadering verklaar dat dit verkeerd was om 'n bepaalde regeringsbeleid (apartheid) goed te praat. Dit lê nie op die weg van die Algemene Kerkvergadering om politieke beleide goed of af te keur nie. Hierdie erkenning beteken nie dat die Algemene Kerkvergadering die huidige of 'n moontlik toekomstige beleid goedkeur nie (NHKA 69ste Algemene Kerkvergadering 2010:329).

Tydens die 69ste Algemene Kerkvergadering van die NHKA het 247 (58.8\%) van die afgevaardigdes ten gunste van die volgende voorstel gestem:

Die 69ste AKV maak in die lig van die 68ste AKV se besluit dat dit verkeerd was om 'n bepaalde regeringsbeleid goed te praat, onomwonde die uitspraak dat apartheid nie teologies geregverdig kan word nie. Die kerk verwerp sy goedkeuring van apartheid omdat dit in stryd is met die evangelie van Jesus Christus, gebaseer is op die idee van onderlinge onversoenlikheid, onreg sanksioneer, en die beeld van God in mense aantas: die vergadering beklemtoon die Bybels-teologiese aard van die uitspraak (NHKA 69ste Algemene Kerkvergadering 2010: 343-344).

Vyf Hervormde dosente, te wete Johan Buitendag, Yolanda Dreyer, James Alfred Loader, Andries van Aarde en Ernest van Eck het in Maart 2009 'n openbare verklaring getitel "Verklaring oor apartheid in kerk en politiek" uitgereik waarin hulle apartheid as verkeerd en die teologiese verdediging daarvan as 'n mistasting beoordeel het (Van Eck 2017:2). Die Verklaring stel dit kategories:

Apartheid kan nie aanvaar of goedgepraat word deur Christene nie omdat: dit gebaseer is op 'n beweerde ongelykheid tussen mense 
wat in die pad kom van die bediening van die versoeningswerk van Christus; dit eksklusiewe voordele aan wit mense ten koste van swart mense gegee het; daar ongeregtigheid en onderdrukking plaasgevind het in onder andere die destydse gedwonge menseverskuiwings wat die gesinslewe van miljoene mense verwoes het; dit die beeld van God in mense aantas - wat die Heilige Gees bedroef (NHKA 69ste Algemene Kerkvergadering 2010: Besluit 54).

Die verklaring het tot 'n uitgebreide debat oor die onderwerp in die NHKA gelei (NHKA 69ste Algemene Kerkvergadering 2010:108). Op die 69ste AKV van die NHKA het 'n beskrywingspunt na aanleiding van die verklaring van die teologiese dosente oor apartheid gedien, naamlik beskrywingspunt 54 .

Die 69ste Algemene Kerkvergadering maak in die lig van die 68ste Algemene Kerkvergadering se besluit dat dit verkeerd was om 'n bepaalde regeringsbeleid (apartheid) goed te praat, onomwonde die uitspraak dat apartheid nie teologies geregverdig kan word nie. Die Kerk verwerp apartheid omdat dit in stryd is met die evangelie van Jesus Christus, gebaseer is op die idee van onderlinge onversoenlikheid, onreg sanksioneer, die beeld van God in mense aantas (NHKA 69ste Algemene Kerkvergadering 2010:108).

As motivering word die volgende aangedui:

Ons ken geen ander evangelie nie as die evangelie van God se liefde in Christus wat van ons eis om met ander deernis te hê soos God met ons deernis het. Daarom kan ons die apartheidsisteem in kerk en samelewing nie anders as inherent mensonterend sien nie. Terwyl die aantasting van menswaardigheid op geen manier Bybels, teologies of moreel geregverdig kan word nie, dring die evangelie sowel mense wat deur onregverdige strukture bevoordeel is as dié wat nie bevoordeel is nie, om sulke regverdigingspogings te weerstaan (NHKA 69ste Algemene Kerkvergadering 2010:108).

Die 69ste Algemene Kerkvergadering, het die beskrywingspunt aanvaar. Die NHKA het hiermee sy goedkeuring van apartheid afgewys. Beskrywingspunt 54 was met 'n oorweldigende meerderheid aanvaar. Altesaam 133 afgevaardigdes het egter hul stem in die minderheid 
laat aanteken. Op dieselfde kerkvergadering het egter ook talryke beskrywingspunte gedien wat betrekking daarop het dat die NHKA behoort te volstaan met sy besluit oor apartheid tydens die 66ste Algemene Kerkvergadering en dat die NHKA geen verdere verklaring daaroor behoort te maak nie (NHKA 66ste Algemene Kerkvergadering 2001:71174). Die beskrywingspunte het egter verval. Die beskrywingspunte toon egter dat die NHKA ten diepste verdeeld is oor die noodwendigheid van skuldbelydenis, die teologiese regverdiging van apartheid, rassisme, versoening en die identiteit van die NHKA as volkskerk (NHKA 69ste Algemene Kerkvergadering 2010:349).

Die 69ste AKV het in 2010 die teologiese begronding van apartheid as strydig met die evangelie verklaar. Daar is met 256 teen 192 stemme (57\%) die volgende besluit geneem: "Die Nederduitsch Hervormde Kerk van Afrika verklaar dat die politieke beleid van apartheid wat toegepas is in die Republiek van Suid-Afrika, nie teologies geregverdig kan word nie, en herroep hiermee alle goedkeuring in die verlede van die beleid in uitsprake deur die Kerk en namens die Kerk. Dit was in stryd met die evangelie van Jesus Christus” (NHKA Algemene Kerkvergadering 2011:85; Dreyer 2014).

Die term "volkskerk" is gevolglik in die kerkwet van die NHKA geskrap. Die besluit het uiteindelik tot kerkskeuring gelei. Wim Dreyer noem tereg dat Besluit 54 histories gesproke 'n waterskeiding in die NHKA se teologiese nadenke en amptelike standpunte oor apartheid verteenwoordig. (Dreyer 2013:1). Pogings om met die beswaardes te versoen het op niks uitgeloop nie.

Op 12 November 2011, waartydens 66 gemeentes van die NHKA verteenwoordig was met 'n totale bywoning van 268 lidmate, is 'n belydenisgespreksgroep in die lewe geroep wat steeds Hervormers wou bly. ${ }^{2} \mathrm{Hul}$ staan sedert 2013 bekend as die Bond van Onafhanklike Hervormde Kerke en is 'n losse federasie van kerke. Hulle beskou hulself as die voortsetting van die NHKA en wou nie van die NHKA skeur nie. Hulle sien hulself as volkskerk en dui aan in hul kernwaarhede dat "volkskerk" bloot dui op 'n "praktiese manier van evangeliebediening". Dit beteken dat die Bond van Onafhanklike Hervormde Kerke glo dat die Woord van God op "elke mens

2 https://www.geloofsbond.org.za/so-glo-ons/geskiedenis 
in sy eie taal en kultuur 'n appèl rig om kerk te wees" (Kernwaarhede van die Bond van Gereformeerde Kerke).

\section{Die GKSA oor die beskerming van volksidentiteit as 'n Godgegewe roeping na demografiese eenheid}

In 1859 is die GKSA as 'n Nederlandse kerkverband gestig. Sendingwerk onder die inheemse volkere was sedert daardie datum gedoen (Acta GKSA 2018:56). In 1957 is die eerste algemene vergadering van die nieAfrikaanssprekende kerke gehou. Laasgenoemde verwys na kerke wat deur die vrug van die GKSA tot stand gekom het. 'n Klassis vir al die kerke wat weens sendingwerk ontstaan het, het tot stand gekom. Die klassis kon egter geen bindende besluite neem nie en het meer as 'n konferensie van kerke gefunksioneer (Acta GKSA 2018:56-57). Die eerste Algemene Kerkvergadering vir kerke wat vanuit die vrug van die sending van die GKSA ontstaan het, het in 1962 plaasgevind. Dit het gelei tot die totstandkoming van drie Nasionale Sinodes volgens etniese en rasbepaalde lyne, naamlik die Sinode Suidland vir die bruin Afrikaanssprekendes, Sinode Soutpansberg vir die Tshivenda- en Xitsonga-sprekende kerke en Sinode Middellande vir al die oorblywende swart kerke. Die Sinode Potchefstroom sou voortgaan vir die GKSA Kerke vir wit lidmate (Acta GKSA 2018:57).

Die GKSA, anders as die NHKA en die NGK, bestaan in een kerkverband met al bovermelde sinodes, en vergader in een Algemene Sinode saam met die ander Nasionale Sinodes (Helberg 1991:496). Vanaf 2006 het die Nasionale Sinodes verval en daarna is daar net een Algemene Sinode. Oor eenheid en verskeidenheid het die GKSA dit reeds in 1967 kategories gestel dat "God wil geen eendersheid nie" met 'n beroep op Genesis 1, 10,11 en Handelinge 17:26. Verdere afleidings uit genoemde tekste is dat "die sonde alles gelykskaaf tot die enersheid van Babel, dat valse eenheidstrewe en uitwissing van grense onskriftuurlik is en na die ryk van die Antichris lei, dat elke volk geroep is om sy volkseie te bewaar en dat kosmopolitisme in stryd is met die ordinansie van God" (Acta GKSA 1967:187). Die GKSA beklemtoon "volkseie" identiteit wat bewaar behoort te word en beskou die uitwissing van grense onskriftuurlik. Die Nasionale Sinode het onder andere Handelinge 17:26 gebruik as Skrifbewys dat God vir "elke volk'n plek gegee het, dit wil sê dat elke volk sy eie grondgebied moet hê" (Acta 
GKSA 1967:187). Verder het die Nasionale Sinode 1967 dit gestel dat die opdrag aan die meer ontwikkelde volk is om die sogenaamde minder ontwikkelde volkere te ontwikkel as "die genadige beskikking van God" en om as voog op te tree (Acta GKSA 1967:187) Die GKSA beweeg van die voorveronderstelling uit dat hulle aangestel is as voog oor die swart en bruin Afrikaanssprekende kerke en Nasionale Sinodes.

Alreeds gedurende die 1980's het verskeie Nasionale Sinodes tot die gevolgtrekking gekom dat die verhoudinge tussen Kerke en Klassisse, geskoei op etniese lyne, nie langer kon voortduur nie. Die Sinode Suidland, dit wil sê die Sinode vir die bruin Afrikaanssprekendes, het in 1990 verklaar dat daar geen rede is om as deel van die Nasionale Sinode voort te bly bestaan nie en het die kerke onder sy ressort aanbeveel om deel te word van naburige klassisse van die Sinode Potchefstroom (dit wil sê, die GKSA kerke vir wit Afrikaanssprekendes).

Die Sinode Soutpansberg, dit wil sê, die GKSA-sinode vir die Tshivendaen Xitsonga-sprekende kerke, het in 1991 'n offisiële versoek aan die Sinode Potchefstroom gerig: "Om daaraan te werk om verhoudinge sodanig te reël dat naburige kerke saamleef met mekaar". Die Sinode Middellande, wat gekonstitueer was om alle ander taalgroeperinge onder swart mense te akkommodeer, het tydens verskeie Sinodes $(1983,1985,1987)$ besluit dat meerdere vergaderings nie op grond van etnisiteit georganiseer moes word nie, maar geografies ingedeel moes word. Daarom het hulle in 1991 besluit om die Algemene Sinode van die GKSA (1992) te versoek om toe te sien dat die geografiese beginsel toegepas word. Die Sinode Potchefstroom het in 1997 besluit dat beide geografiese en kulturele organisasie gehandhaaf moes word. In 2003 word besluit dat die geografiese beginsel toegepas moes word (Acta GKSA 2018:58).

Die Nasionale Sinode 1985 het die beroep op die Skrif vir die verskynsel van volke en lande verwerp en het dit gestel dat die Bybel behoort oor volke en lande deskriptief (beskrywend), en nié preskriptief (voorskriftelik) nie, vertolk te word (Acta GKSA 1985:429-430). Op die vraag of verskillende volke in dieselfde land kan woon en nog hulle identiteit kan behou, kan nie sonder meer uit die Skrif 'n antwoord gegee word nie, sê die Sinode van 1985 (Acta GKSA 1985:430; Acta GKSA 2000:521). Met betrekking tot die voogdyskap van die GKSA, stel die Sinode van 1985 dit duidelik dat die 
Bybel nie regstreeks gegewens verskaf om die vraag te beantwoord wie of wat die volk is wat op Suid-Afrikaanse land aanspraak kan maak nie, en ook nie wat die aanspraak behels nie (Acta GKSA 1985:429, 3.1.3)

Die Nasionale Sinode van 1988 het die 1967-besluite met 'n nuwe formulering vervang. Geen besluit kon gevind word wat die 1967-besluit herroep nie (Handelinge GKSA 2000:519-521). Dit is belangrik om daarop te let dat die Nasionale Sinode van 1988 die eenheid van die menslike geslag primêr stel: "In die loop van die geskiedenis roep God volke, nasies en tale in aansyn. God bepaal hoe lank nasies en volke sal bestaan en waar hulle sal woon (Hand17:26)" (Acta GKSA 1988:50-51,3.2; .3.). Die GKSA 1988 Sinode het vervolgens verklaar dat "die handhawing, verandering en/of opheffing van volksidentiteite val onder God se regering, terwyl die Heilige Skrif hieroor geen voorskrifte gee nie" (Acta GKSA 1988:50-51). Dit is duidelik uit bovermelde dat die 1967 en 1988 besluite teenoor mekaar staan. Die GKSA Sinode het egter nie die 1967 besluit wat te doen het met die beskerming van volksidentiteit as 'n godgegewe roeping, herroep nie. Dit het ten onregte daartoe gelei dat lidmate van die GKSA hul op die 1967-besluit beroep (en daarmee ook op die Skrifgegewens wat daarby gegee is), asof dit nog geldig is.

Die GKSA het op die 47ste Nasionale Sinode te Potchefstroom 'n beskrywingspunt van die Suidelike Partikuliere Sinode oor die status van die 1991-besluite in behandeling geneem. Die 1991 Sinodebesluit oor apartheid lui soos volg:

... that the ideology of apartheid, which is a political and social system by which human dignity is adversely affected, and whereby one particular group is detrimentally suppressed by another, cannot be accepted on Christian ethical grounds because it contravenes the very essence of reconciliation, neighbourly love and righteousness, the unity of the church and inevitably the human dignity of all involved and therefore is a sin and the biblical justification of it is a heresy (Acta GKSA Nasionale Sinode 1991:157,160-169).

'n Beskrywingspunt wat in 2000 ingedien is, het die Sinode opgeroep om te bevestig dat die 1991 besluit oor apartheid as kerklike besluit geldend is en te onderneem om besluite en handelinge wat met genoemde besluit in stryd is, as herroep (gerojeer) te beskou (Handelinge GKSA 2000: 519). 
Die Nasionale Sinode van die GKSA 2000 het egter besluit om nie die beskrywingspunt goed te keur nie. As motivering vir bovermelde besluit, dui die Sinode aan dat die beskrywingspunt versoek dat daar met kerklike besluite gehandel moes word op 'n wyse wat strydig is met Artikel 31 van die Kerkorde. Die artikel het te doen daarmee dat kerklike vergaderinge slegs kerklike sake op 'n kerklike wyse behoort te hanteer. Verder dui die artikel aan dat meerdere vergaderings slegs sake wat nie deur mindere vergaderings afgehandel kan word nie, of wat van belang is vir die Kerke as kollektief, kan hanteer. Tweedens word gemotiveer dat die beskrywingspunt die ideologie van apartheid verwar met besluite van die sinodes wat geneem is oor volkereverhoudinge op grond van die Skrif, Belydenis en die Kerkorde. Derdens word aangedui dat die beskrywingspunt nie aantoon watter ander besluite van die verlede slegs oor die ideologie van apartheid handel nie. Laastens word aangedui dat dit nie duidelik is, "watter besluite (indien enige) gerojeer moet word nie" (Handelinge GKSA 2000:521). Gevolglik word in die GKSA die 1991 besluit nie as die beslissende uitspraak oor "volkere-verhoudinge" beskou nie.(Ibid. 520; Acta GKSA 1991:649-652. Op die Nasionale Sinode van 1994 is 'n Meerderheids- en Minderheidsrapport van die Deputate vir Korrespondensie met ander Sinodes (Middellande, Soutpansberg en Suidland) in behandeling geneem. Die Meerderheidsrapport het instemmend verwys na die 1991 se besluit, terwyl die Minderheidsrapport daarna verwys het as 'n uitspraak wat wys op die "gevaar" dat apartheid tot 'n ideologie verhef kan word (Acta GKSA 1994:591-608; Acta GKSA 1994:595,1.7.2; Acta GKSA 1994:603,1.2.4.1.) In die lig van die Sinodebesluit 1991 was 'n beskrywingspunt op die Nasionale Sinode van die GKSA 1997 in behandeling geneem:

Die Sinode word versoek om hom te verantwoord oor die vraag of die Gereformeerde Kerke in Suid-Afrika 'n bepaalde aanspreeklikheid moet aanvaar vir die staatkundige-sosiale verlede van Suid-Afrika met betrekking tot die vestiging en uitvoering van die beleid van afsonderlike ontwikkeling of apartheid, en indien sodanig aanspreeklikheid bevestig of ontken sou word, wat die Here van die kerk in hierdie verband verwag (Acta GKSA 1997:871).

Op grond van artikel 30 van die Kerkorde, het die GKSA nie die beskrywingspunt goedgekeur nie (Ibid. 1997:872). Die GKSA het artikel 30 gebruik om gesprek oor apartheid en/of afsonderlike ontwikkeling te 
stol. So van 'n diskoers oor versoening het min tereggekom. Veel eerder is aandag verleen aan demografiese eenheid van gemeentes bestaande uit persone van verskillende taal en kultuur groeperinge.

\section{Ten slotte: Gesamentlik op weg na 'n teologie van inklusiwiteit}

Die Afrikaanse gereformeerde kerke het apartheid moreel en teologies geregverdig. Lidmaatskap van die Afrikaans gereformeerde kerke was beperk tot wit mense. Aparte kerke vir elke taal- en kultuurgroepering in Suid-Afrika is deur die Afrikaans gereformeerde kerke gekonstitueer. Uit bovermelde blyk dit dat die Afrikaanse gereformeerde kerke die afgelope drie dekades noodwendig aandag moes verleen aan die resolusie van die WBGK met betrekking tot die teologiese regverdiging van apartheid, Skrifverstaan, lidmaatskap van kerke, die begrippe volk en "volkskerk", asook die Belhar-belydenis. Heftige debatvoering is op sinodale vlak oor bovermelde sake gevoer, en etlike verklarings was uitgereik. Hierdie diskoers het uiteindelik tot kerkskeuring gelei, byvoorbeeld die vroeëre stigting van die Afrikaanse Protestante Kerk in 1987, en die Bond van Gereformeerde Kerke in 2013. Hierdie kerkformasies toon aan dat daar 'n sektor in die gereformeerde kringe in Suid-Afrika is wat steeds vashou aan kultuur-identiteit as vereiste vir lidmaatskap in 'n kerk.

Uit bovermelde is dit duidelik dat die identiteitspolitiek 'n groot rol gespeel het in die diskoers oor rassisme en versoening. Ook die VGKSA kon nie daarvan ontsnap nie. Van regstellende geregtigheid kom egter min tereg in die diskoers oor versoening en rasseverhoudinge in die GKSA, veral op plaaslike vlak. Veel eerder is meer klem gelê om op sinodale vlak besluite oor verbandhoudende sake te neem. Ek is van mening dat in die diskoers oor rassisme en versoening aandag behoort verleen te word aan die Bybelse en Judees-Christelike verstaan van versoening, oftewel regstellende geregtigheid. Die NGK Algemene Sinode het aangedui dat die NGK

'n Duidelike getuienis teenoor die staat wil lewer oor versoenende geregtigheid. Dit beteken dat reg en geregtigheid ten opsigte van die regte en menswaardigheid van alle mense (wat dus vanselfsprekend die hele boerderygemeenskap insluit) tot uitvoering moet kom - en 
dus ook in die kerk" (NGK Algemene Sinode Agenda 2011:A.11 Bylaag 3;2011:226 pt 4.2).

Versoening in die Joodse tradisie het altyd te make met die herstel van die reg. Volgens 'n Joodse geleerde, Eliezer Segal (2001:183), het opregte berou wat tot versoening tussen die partye betrokke kan lei, te make met belydenis, afkeer en 'n sterk wil om die reg te herstel. (Segal 2001:181197). Volgens Paulus is dit God wat die inisiatief neem in versoening (2 Kor 5:19). Daarsonder sal versoening tussen rassegroepe in die SuidAfrikaanse konteks 'n blote akademiese oefening bly. Omdat die afwysing van die teologiese regverdiging van apartheid uiteraard ook handel oor volksidentiteit, nasionalisme, natuurlike diversiteit, behoort die Afrikaanse gereformeerde kerke, insluitend die VGKSA, veel meer te doen om dit te help dekonstrueer en 'n nuwe identiteit in Christus te probeer bevorder en te vestig (Gal 3:26-28).

\section{Bibliografie}

Belydenis van Belhar. 1986. Belhar: Lusboekwinkel.

Bond van Gereformeerde kerke. [Intyds]. Beskikbaar: https://www. geloofsbond.org.za/so-glo-ons/geskiedenis

Buitendag, J. 2006. Coming in from outside: A crucial event in the history of ecumenism of the Nederduitsch Hervormde Church. HTS Teologiese Studies/ Theological Studies 62(3):813.

DRC/DRCA/URCSA Church Property Settlement Panel Final Report and Settlement Recommendations December 2012.

Dreyer, W.A. 2006. Die Nederduitsch Hervormde Kerk van Afrika as volkskerk: Oorsig en herbesinning. HTS Teologiese Studies/ Theological Studies 62(4).

Dreyer, W.A. 2011. Journey from isolation. HTS Teologiese Studies/ Theological Studies 67(1).

Dreyer, W.A. 2013. Die Hervormde Kerk en apartheid. HTS Teologiese Studies/ Theological Studies 69(1). 
Dreyer, W.A. 2014. Wanneer een twee word: 'n Perspektief op resente gebeure in die Nederduitsch Hervormde Kerk van Afrika. HTS Teologiese Studies/ Theological Studies 70(1).

Esselenpark Verklaring 21 en 22 Junie 2006.

GKSA. 1967. Acta.

GKSA. 1985. Acta.

GKSA., 1988. Acta

GKSA. 1991. Acta

GKSA. 1994. Acta

GKSA. 2000. Acta.

GKSA. 2018. Acta.

GKSA. 1997. Handelinge.

GKSA. 2000. Handelinge.

GKSA. 2016. Handelinge.

GKSA 2018. Handelinge.

Helberg, JL. 1991. 'n Toets vir Gereformeerde ekumene. Skriflig 25(4).

Kerk en Samelewing 1990. 'n Getuienis van die Nederduitse Gereformeerde Kerk. 1990. Bloemfontein: Pro Christo-Publikasies.

Kerkorde van die Nederduitsch Hervormde Kerk van Afrika. Pretoria: Kerkargief.

Kerkwet van die Nederduitsch Hervormde Kerk van Afrika.1951. Pretoria: Kerkargief.

Kernwaarhede van die Bond van Gereformeerde Kerke.

Nederduitse Gereformeerde Kerk (OVS), Nederduitse Gereformeerde Kerk in Afrika (Phororo) en die Verenigende Gereformeerde Kerk in SuiderAfrika, saaknommer 536/96:31.

NGK. 1982. Handelinge Algemene Sinode Nederduitse Gereformeerde Kerk. 
NGK. 1986. Agenda van die Algemene Sinode.

NGK. 1994a. Agenda van die Algemene Sinode.

NGK. 1994b. Besluiteregister van die Algemene Sinode.

NGK. 1998a. Acta van die Algemene Sinode.

NGK. 1998b. Besluiteregister van die Algemene Sinode.

NGK. 2004. Besluiteregister van die Algemene Sinode.

NGK. 2011. Agenda van die Algemene Sinode.

NHKA. 1997. Algemene Kerkvergadering. Pretoria: Kerkargief.

NHKA. 2001 Algemene Kerkvergadering. Pretoria: Kerkargief.

NHKA. 2004. Algemene Kerkvergadering. Pretoria: Kerkargief.

NHKA. 2001. Besluitebundel van die 66e Algemene Kerkvergadering. Pretoria: Kerkargief .

NHKA. 2004. Besluitebundel van die 67e Algemene Kerkvergadering. Pretoria: Kerkargief.

NHKA. 2010. Besluitebundel van die 69e Algemene Kerkvergadering. Pretoria: Kerkargief.

NHKA. 1973. Herderlike skrywe van die Algemene Kerkvergadering.

NHKA. 1990. Herderlike skrywe van die Algemene Kerkvergadering.

NHKA. Kommissie van die AKV 2006. Korrespondensie aan kerkrade 7 September 2006. Pretoria: Kerkargief.

Park, E.C. 2003. Either Jew Or Gentile: Paul's Unfolding Theology of Inclusivity. London: Westminster John Knox Press.

Pont, A.D. 1969. Kerk en volk. HTS Teologiese Studies/ Theological Studies 25(3).

Pont, A.D. 1986. Verbond en volkskerk. HTS Teologiese Studies/ Theological Studies 42(1):28-76. 
Pont, A.D. 1991. Die verhouding "kerk en volk" in die jare 1835-1900 in die Oorvaalse: 'n Terreinverkenning. HTS Teologiese Studies/ Theological Studies 47(3).

Ras Volk en Nasie en Volkereverhoudinge in die lig van die Skrif. 1975 Kaapstad: Nasionale Boekery Beperk.

Segal, E. 2001. Jewish Perspective on Restorative Justice. In Michael L. Hardely (ed.) The Spiritual roots of Restorative Justice. New York: State University of New York Press). 181-197.

Van der Merwe, B. en Oelofse, M. 2011. Teologiese twis rondom sinodale koersveranderinge in die Nederduitse Gereformeerde Kerk, 19821990. Historia 56:154-168.

Van der Merwe, J.M. 1990. Ras, Volk en Nasie en Kerk en Samelewing as beleidstukke van die Ned. Geref. Kerk - 'n Kerk-historiese studie. DDproefskrif, Universiteit van Pretoria.

Van Eck, E. 2017. Om die Rubicon oor te steek: Oopmaak van die hekke in die Nederduitsch Hervormde Kerk van Afrika/Crossing the Rubicon: Opening of gates in the Netherdutch Reformed Church in Africa. HTS Teologiese Studies/ Theological Studies.

Verklaring oor apartheid in kerk in politiek - Besluit 54 van die Algemene Kerkvergadering van die Nederduitsch Hervormde Kerk van Afrika, 2010. HTS Teologiese Studies/ Theological Studies 73(1).

WARC General Council 1983. Ottawa Proceedings of the 21st General Council, Geneva: WARC. 176-180.

WARC General Council. Called to Witness to the Gospel Today, Studies from the World Alliance of Reformed Churches 1, Geneva: WARC Publication.

WARC General Council 1990. Seoul Proceedings of the 22nd General Council, ed. Edmond Perret. Geneva: WARC Publication.

WARC General Council meeting in Debrecen, Hungary in August 1997. A pastoral letter. Geneva: WARC Publication. 
